\title{
Postcolonial Aesthetics: Talempong Kreasi and Talempong Goyang in West Sumatra
}

\author{
Andar Indra Sastra, Nadya Fulzi, Syahri Anton \\ E-mail: andarstsipp@gmail.com
}

\begin{abstract}
The aim of this article is to disclose the postcolonial aesthetics of talempong kreasi and talempong goyang in West Sumatra. Aesthetics can be defined as a sense of perception or the various kinds of feelings that are aroused by an art object that is being observed. Postcolonialism is understood to be the continuation of colonialism; hence postcolonial aesthetics discusses the sense of perception, in this case with reference to talempong kreasi and talempong goyang as the material object. Talempong is a type of bronze musical instrument found in West Sumatra; the word kreasi means 'creation' or something new, while the word goyang means 'rocking' or 'swaying' and refers to the body movements of the spectators as they appear to dance in time to the talempong music. The addition of the words kreasi and goyang after the word talempong create the impression that this type of music belongs to the domain of popular music. The emergence of these two concepts in West Sumatra cannot be separated from the influence and power of a number of leading figures in the field of education - specifically artists - from the colonial era, who had a background in Western music education. Talempong kreasi and talempong goyang are dynamic in nature and have the ability to play both major and minor melodies as the talempong instruments are tuned to chromatic pitches. The tuning system of the talempong is akin to that of diatonic musical instruments, and as a musical system it presents the harmonies of Western music through its melodies and chords. The problem to be addressed in this article focuses on postcolonial aesthetics, with talempong kreasi and talempong goyang in West Sumatra as the material object of the study. This phenomenon is examined using the postcolonial theory, relying on qualitative data which is supported by additional qualitative data. The results of the research show that talempong kreasi and talempong goyang in West Sumatra are a product of postcolonialism.
\end{abstract}

Keywords: aesthetics, postcolonial, talempong kreasi, talempong goyang, West Sumatra.

\section{INTRODUCTION}

Aesthetics is often defined as a sense of perception or the various kinds of feelings (raso, rasa) aroused (Ali, 2011: 1-2; Pramono, 2009: 1; Suryajaya, 2015: 1). These feelings may offer a certain sensation or impression to the art observer; in this case talempong kreasi and talempong goyang are the object which leads to this aesthetical perception and all its complexity. Essentially, an object that is perceived cannot be separated from the role of the subject, or the person whose role is to give value to the object.

The connection between the object and the subject is vital when viewing the topic of aesthetics. Aesthetics is not only concerned with the matter of beauty but also the matter of feeling or raso. An interaction between human beings in which there is an indication of pleasure is a dialogical relationship because there is a concern for value a dialectical phenomenon involving the object and 
subject concerned. The subject of interest in this case is related to the thought concepts of a number of leading figures in the field of art education in postcolonial West Sumatra. Post colonialism is a continuation of colonialism, the impact of which can still be felt even though the colonizers have long since left the country. Thus, postcolonial aesthetics discusses the subject that is concerned with an object - in this case talempong - which musically has the ability to create a particular musical taste, or aesthetic, in accordance with the values and ideology contained therein.

According to Boestanoel Arifin Adam, in Minangkabau the term talempong refers to the type of instruments known as idiophones, which can be found in various shapes and sizes, and may be made from various different materials, and which are played by being struck. In a more general understanding, a talempong is a small gong made from a metal alloy which is struck to produce a sound (Adam, 1986/1987: 9-10) (Andar, 2017: 62). The type of talempong referred to by Adam is a traditional talempong ensemble, played by three musicians, each of whom plays two talempong instruments. The talempong is held (direnjeang) in the left hand and struck (diguguah) with the right hand which holds a special kind of beater (pangguguah), creating a melody characteristic of talempong renjeang Minangkabau - which academics call pacik. Along with the establishment of the art academy, Akademi Seni Karawitan Indonesia (ASKI) Padangpanjang, in 1966, a new kind of talempong emerged - which academics referred to as talempong kreasi, and in its subsequent development has become known as talempong goyang.

Hanefi states that talempong kreasi consists of one set of talempong instruments to play the melody, one set to play the lower accompaniment, one set to play the higher accompaniment, one set of canang to play the lower accompaniment, and one set of canang to play the higher accompaniment [canang are slightly larger than talempong and are tuned an octave lower, and have the same function as the accompanying talempong]. The pitches of the canang are one octave below the pitches of the talempong (Hanefi, et al., 2004: 67). The pitches of the talempong and canang are tuned diatonically. The function of the talempong and canang that provide the accompaniment is to play chords. To complete the talempong orchestra, additional wind instruments - bansi, sarunai, and saluang - are included, as well as a drum. In the case of talempong goyang, Asril states as follows:

Talempong goyang is a genre of Minang music with a new kind of packaging and a 'pop' nuance, which is said to have the potential to become an alternative kind of music for entertainment in the future in West Sumatra - originating from talempong kreasi. Talempong goyang offers the opportunity not only to accompany dance and play instrumental pieces and Minang songs, or dendang, but also to accompany various kinds of pop songs, ranging from "traditional-Minang" pop (songs based on traditional non-diatonic Minang songs that are usually accompanied by the saluang and have been rearranged as pop songs) to "standard-Minang" pop, dangdut-Minang, dangdut, zapin, zapin-ndut, and Indonesian pop. A number of other instruments are also added to produce a richer orchestration. These include two drums (to provide the rhythms of the tabla), a tambourine, a drum set, keyboard, bass guitar, accordion, djembe, as well as the wind instruments bansi and sarunai as a representation of traditional Minang music (Asril, 2012: 11).

Talempong kreasi and talempong goyang are two phenomena that cannot be separated from the subject concerned. By viewing the concept of talempong kreasi and talempong goyang, it is possible to observe the track record of the thought concept of musicians who "forced" their ideology to be adopted by talempong in West Sumatra. A thought concept contains ideological content, ideology works according to the demand of values, and the demand of values makes a person follow his or her desire to act according to the thought concept to which he or she adheres.

In order to explore this matter more deeply, the writer uses the postcolonial theory which Faruk describes as a set of statements about the conditions and tendencies of a society that was once colonized, namely: (1) a society that has been 
colonized is a society whose thoughts, feelings, attitudes, and behaviour are still controlled by the thought concepts of the colonizer; (2) the colonizers' power over these thoughts, feelings, attitudes, and behaviour may be stronger and last for longer than the duration of their power over the geographical territory of the colonized society, and may even continue after the colonizer has relinquished power over this geographical territory; (3) these conditions and tendencies manifest themselves historically, whether in technology, culture, or highly effective strategies of power, in particular since the $19^{\text {th }}$ century XIX (Faruk, 2007: 16).

This research relies on qualitative data, which is supported by additional quantitative data using a method of participant observation. From this study, the writer wishes to gain a better understanding of various existing problems through direct observation and in-depth interviews with a number of informants. Talempong kreasi and talempong goyang was chosen as the topic for this research because the writer already has a general picture of talempong in Minangkabau and wishes to study the specific case of talempong kreasi and talempong goyang that is found in West Sumatra. This case is researched comprehensively by interviewing various related parties, including academics, talempong musicians, and other informants in West Sumatra.

\section{DISCUSSION}

\section{Talempong Kreasi}

When we talk about talempong kreasi, we are essentially talking about a 'new creation' or 'something new' in an existing art genre in West Sumatra. The presence of something new is an indication of social change in the life of the community Arnold Hauser states that social change in a particular cultural region will produce a unique style which matches the form of the community at that time (Hauser, 1974: 547). According to Piotr Sztomka, the way in which people view change plays an important role in encouraging them to act, and therefore has a large impact on the course of change ... enriching people's knowledge about change is practically the same as creating change. The idea of change [in behaviour] is the source for introducing change (Sztomka, 2008: viii). Of course, the idea of change cannot be separated from the thought concepts of certain people - leading figures, and their set of values along with its ideological content - after the era of colonialism, which hereon will be referred to as postcolonialism. Awareness of the significance of change forms the basis of the change - or transformation - in this case from traditional talempong to talempong kreasi and talempong goyang. The change to become talempong kreasi can be divided into two main categories, namely: (1) natural diatonic and (2) chromatic diatonic.

\section{Natural Diatonic}

In the 1970s, changes to talempong were also made by the late Akhiar Adam. Akhiar Adam was the brother of the late Boestanul Arifin Adam, former Director of ASKI Padangpanjang from 1973 to 1976 . The two brothers came from a family of artists, most of whom had a Western music education. Information about the tuning system (mangkoan bunyi) of Akhiar Adam's talempong kreasi was obtained from an interview with Jufri in 2016. In addition to the change in mangkoan bunyi, this talempong kreasi also displays changes in compositional style which tends towards an "orchestral" form of talempong music.

The form of this orchestra consists of a set of talempong and canang instruments that are arranged based on the musical concept of: (1) a set of talempong to play the melody; (2) a set of talempong to accompany the melody, divided into two groups of instruments, namely the basic talempong (talempong dasar) and the high talempong (talempong tinggi) both of which provide the harmony in the form of chords; (3) a set of canang to accompany the melody, consisting of the basic canang and high canang. The set of talempong that plays the melody consists of a single octave of instruments, based on the consideration that the melodies of Minangkabau songs are in the range above the normal pentatonic pitches. Jufri states that Akhiar Adam's talempong 
kreasi uses 'c' as the basic pitch; the set of talempong that plays the melody consists of pitches "c - d - e - f - g - a - b - c". The talempong that accompany the melody consist of two sets; the basic set of talempong is tuned to the pitches "c $-\mathrm{d}-\mathrm{e}-\mathrm{f}$, and the high set of talempong is tuned to the pitches " $\mathrm{g}$ - a - b - c". The accompanying canang are tuned one octave below the accompanying talempong and consist of the basic canang and high canang. The basic set of canang is tuned to the pitches "C - D - E - F", and the high set of canang is tuned to the pitches " $\mathrm{G}$ - A - B - C". This is due to considerations of harmony in a musical composition. To control the accentuation and tempo, a drum, known as gandang kantindik, is also included in the orchestra (Jufri, interview, 2016). In 1972, the talempong kreasi developed by Akhiar Adam was expanded further to include 3 gongs, tuned to pitches "D - G and A"; these act as the tonic notes for chord progressions and provide the bass line in a Combo Band (Jufri, interview, 2016).

At the time of the current research study, Akhiar Adam's model of talempong kreasi is no longer in use at ISI Padangpanjang. Based on the experience of the writer during his time as a student at ASKI Padangpanjang in 1983, the composition of musical structure of talempong kreasi can be presented as in the Diagram 1.

The diagram below clearly shows that the arrangement of talempong kreasi has started to adopt the knowledge of harmony from Western music. The arrangement of the instruments is the same as - or can be converted to - the model of a Combo Band (a set of musical instruments consisting of (1) a drum set; (2) a melody guitar: (3) a rhythm guitar; and (4) a bass guitar) - to play a simple musical composition. This model of composition of a Combo Band appears to have inspired a number of innovators who were interested in making changes to the traditional talempong of Minangkabau. The drum set was replaced by a traditional drum, and in subsequent developments, a number of wind instruments (sarunai, bansi, and saluang) were also included, adapted to the basic pitch of $\mathrm{c}$ natural. It should be mentioned that the use of the word 'chord' with reference to the basic talempong, high talempong, basic canang, and high canang is not the same as the understanding of a chord in the Western music system. The term chord I, II, or III on the talempong is a code for the accompanying instruments to change their rhythm in accordance with the movement of the melody played by the talempong or wind instruments.

\section{Diagram 1.}

\section{Arrangement of a Set of Talempong Kreasi}

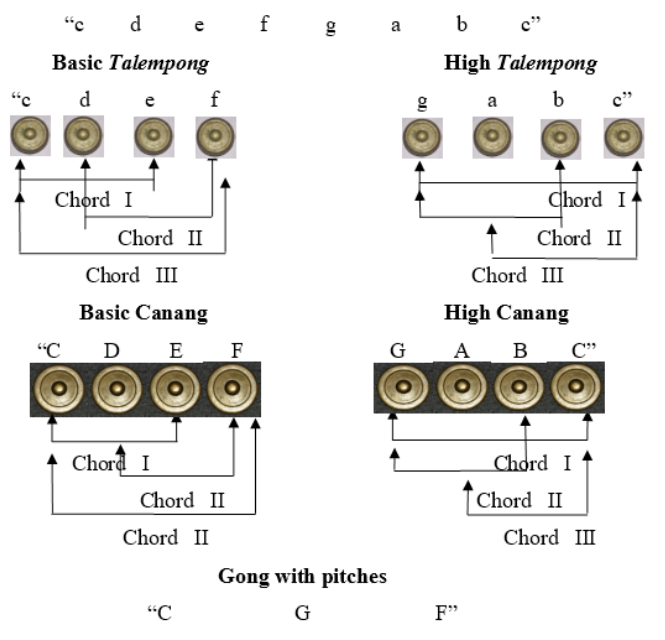

This new model of talempong officially became a part of the curriculum at SMKI and ASKI Padangpanjang, and its melodies presented vocabulary from a variety of rhythmic Minangkabau songs such as dendang Mudiak Arau, Malereang Tabiang, Talago Biru, Tak Tontong, Tanti Batanti, and others. In addition, talempong kreasi also began to be used to accompany new forms of traditional dance, such as Tari Rantak, Tari Panen, Tari Piriang, Tari Gandang, Tari Alang Babega and others. In addition to playing traditional dendang melodies, talempong kreasi at times also plays talempong pacik. The concept of talempong pacik that is used to accompany new forms of traditional dance is based on the principle of chord fragments in which talempong 1 is paired with talempong 3 (do and mi), talempong 2 with 4 (re and fa), and talempong 5 by itself (sol). The talempong pair 1 
and 3 is known as talempong Dasar, the talempong pair 2 and 4 is called talempong Paningkah, and talempong 5 is referred to as talempong Anak.

Talempong Dasar is played by the musician who plays the talempong melody, talempong Paningkah by the musician who plays the basic accompanying talempong, and talempong Anak by the musician who plays the high accompanying talempong. The basic set of accompanying talempong consists of 4 instruments tuned to pitches c, d, e, and f or do, re, mi, and fa. The high set of talempong consists of pitches $\mathrm{g}, \mathrm{a}, \mathrm{b}$, and $\mathrm{c}$ or sol, la, si, and do.

The way in which talempong kreasi is packaged as an art form has undergone changes in terms of its aesthetics. Laksono, quoting Haryono in Resital, states that as part of a culture, an art form cannot be separated from the dimensions of space and time. In terms of its spatial dimension, a work of art has a variety of styles which exist within the same time, because a work of art exists within the socio-cultural context of its supporting community. In terms of the temporal dimension, a work of art can experience development and change because it is strongly dependent upon the context of the age in which it exists (Laksono, 2008: 88). A change in feel is marked by the mangkoan bunyi (tuning system) of the talempong which is based on the diatonic music system. Likewise, the pairing of the talempong refers to chord fragments or a model of musical harmony.

A change in aesthetics occurs when the system for regulating the pitch levels of the talempong instruments is based on the standard of conventional - Western - music, or the aesthetics of diatonic music. A conventional music system always takes into consideration the intervals between one note and the next. Hastanto writes that according to the system of equal temperament, in which all pitches of the diatonic scale are an equal distance apart such as on the piano, a single octave $=1200$ cents. A semitone -100 cents. Therefore, the interval $\mathrm{c}-\mathrm{c} \#=100$ cents, and the interval $\mathrm{c}-\mathrm{d}$ $=200$ cents (Hastanto, 2012: 11). This concept of equal temperament is the basic thought behind the change in the aesthetics of the talempong - in the new model of talempong kreasi and subsequently talempong goyang. The change in aesthetics of the talempong has a direct impact on the musical feel, or raso when the talempong is played. This change in raso is due to the fact that the regulation of talempong pitches is based on the principle of diatonization or the application of the principle of diatonic music.

\section{Chromatic Diatonic}

Chromatic diatonic is a diatonic music system which includes semitones. Hanefi et al state that the main change that has taken place with the talempong instruments that play the melody in a number of groups is the addition of chromatic pitches. The primary reason for this is so that they are able to play songs with melodies - in Western style - that include chromatic pitches, so that they can be performed by a talempong kreasi ensemble. The inclusion of chromatic pitches was originally introduced by the music group Sanggar Syofyani under the leadership of Yusaf Rahman in 1974 (Hanefi, et al, 2004: 70). Asril states that the range of musical genres that can be played on talempong kreasi stretches to dangdut, and this has had an impact on this musical genre. The character of dangdut music, with its rhythmic patterns played by the tabla, arouses the audience's desire to dance or sway (goyang), especially when the artists themselves are dancing, and this led to the name talempong kreasi being changed to talempong goyang by members of the community and the performers themselves. The name talempong goyang does not mean that the musicians dance or sway while they play but rather refers to the rhythm of the music which encourages the audience to dance (Asril, 2012: 12).

Yusaf Rahman is an educational leader who made changes to talempong by adopting his knowledge of Western musical harmonies and creating a talempong orchestra. He was a musician who had a background in Western music education and played several Western instruments, including violin, piano, cello, and clarinet. According to Asril, Yusaf Rahman's musical compositions have inspired and been used by numerous dance groups in both West Sumatra and Jakarta. One special feature of Yusaf Rahman's talempong kreasi compositions and attractive performance style is the high level of skill of Tuen Islamidar, who plays the melodies using a "triller" technique, making the talempong melodies tighter, full of life, 
and filled with variation. Islamidar has a unique style of playing talempong. He does not play the notes in ascending or descending order but plays high and low notes alternately, from left to right, creating an elegant and attractive style for playing the talempong melody (Asril, 2012: 11).

The talempong kreasi developed by Yusaf Rahman consists of: (1) two sets of talempong to play the melody: (2) one set of accompanying talempong tingkah; (3) one set of accompanying talempong saua; (4) two drums - gandang tambua and gendang bonggo; (5) four wind instruments, comprising a saluang, sarunai, bansi, and seruling and; (6) one bass guitar, as well as a keyboard and a sound system. In subsequent developments, almost all talempong kreasi groups began to use chromatic pitches, including the Indojati art group, Sendratasik art group from IKIP Padang -in 1999 IKIP changed status to become Universitas Negeri Padang (UNP) - Eli Kasim's art group, and other groups both inside and outside West Sumatra. Talempong kreasi is used to accompany new creations of Minang dance by Syofyani, such as Tari Pasambahan, Tari Piriang, Tari Payuang, and others. These talempong ensembles are also used to perform instrumental music based on the vocabulary of traditional Minangkabau songs or dendang, such as Talago Biru, Mudiak Arau, Andam Oi, and so on.

\section{Talempong Goyang}

Talempong goyang is a transformation of talempong kreasi. Hanefi et al state that the word goyang can be defined as a movement of the body, like dancing, that accompanies the performance of talempong music. The addition of the word goyang after the word talempong creates the impression that this type of music belongs to the domain of popular music. Traditionally, talempong music in Minangkabau was never played while dancing or swaying, nor did audiences of talempong kreasi dance or sway as they watched a performance. Dancing while singing, and inviting the audience to join in, is a practice commonly found at pop concerts (Hanefti et al, 2004: 69). In principle, talempong goyang is almost the same as talempong kreasi that was developed by Yusaf Rahman in that its musical system includes chromatic pitches.

The instruments commonly found in a talempong goyang ensemble - specifically Alfalah's group - include: (1) two sets of talempong to play the melody; (2) a drum set; (3) a set of wind instruments, comprising saluang, sarunai, and bansi; (4) a melody guitar; (5) a bass guitar; (6) a keyboard and; (7) a set of Sundanese drums. Alfalah states that a large ensemble of talempong goyang may use 20 talempong to play the melody and 20 talempong to accompany the melody, arranged in two rows. The pitches of the talempong on the front row are G\#, B, A, G, d\#, f\#, g\#, a\#, f, e, and on the back row a\#, c, d, e, f, g, a, b, c, d (Alfalah, interview, 22-06-2014). For a clearer picture, see the diagram below.

Diagram 2.

Arrangement of pitches on talempong goyang

\begin{tabular}{|c|c|c|c|c|c|c|c|c|c|}
\hline $5 \#$ & 7 & 6 & 5 & $2 \#$ & $4 \#$ & $5 \#$ & $6 \#$ &. &. \\
\hline $6 \#$ & 1 & 2 &. & & & & & 4 & 3 \\
\hline
\end{tabular}

\begin{tabular}{|c|c|c|c|c|c|c|c|c|c|}
\hline $5 \#$ & 7 & 6 & 5 & $2 \#$ & $4 \#$ & $5 \#$ & $6 \#$ &. &. \\
\hline $6 \#$ & 1 & 2 & 3 & 4 & 5 & 6 & 7 &. & 2 \\
\hline
\end{tabular}

The mixing of two traditions is also found in the playing patterns used. This hybridization of various different musical instruments, scales, and tuning systems makes it possible for talempong goyang ensembles to perform a range of different pieces, from standard Minang pop music to dangdut, either in the Minang language or Indonesian, and a variety of other instrumental music based on the vocabulary of traditional Minang songs.

Talempong goyang is more than simply a combination of the playing of musical instruments from two different traditions. Within the frame of view of popular culture, according to Fiske, in Budi Santosa, the use Western musical instruments such as the keyboard, electric guitar, and drum set, together with traditional instruments, is an example of the adoption of technology through the use of a commodity (the musical instrument) - in which the musical instrument produces itself ideologically in the form of a commodity. Hence, the commodity produces the ideology of the system from which it has been produced - a commodity is an ideology 
that has been manifested in material form (Santoso, 2003: 210). The adoption of an ideology through the knowledge system of Western music can be seen in the arrangement of the talempong goyang pitches (see diagram 2 above).

Through the arrangement of the instrumentation, a talempong goyang ensemble, with the support of professional players, can perform various kinds of instrumental music based on the vocabulary of traditional Minang songs and also accompany various Minang pop songs and Minang dangdut songs. Asril states that this tendency appears to be in line with the development of the recording industry in West Sumatra. The development of Minang pop songs in the 1970s was marked by the appearance of new compositions of Minang popular music, some of which was based on the vocabulary of traditional Minang songs and some of which was newly composed by artists at that time (Asril, interview, 2017) - see photo below.

Photo 1.

Talempong goyang uses a number of Western and electronic musical instruments such as guitar, keyboard, and drum set.

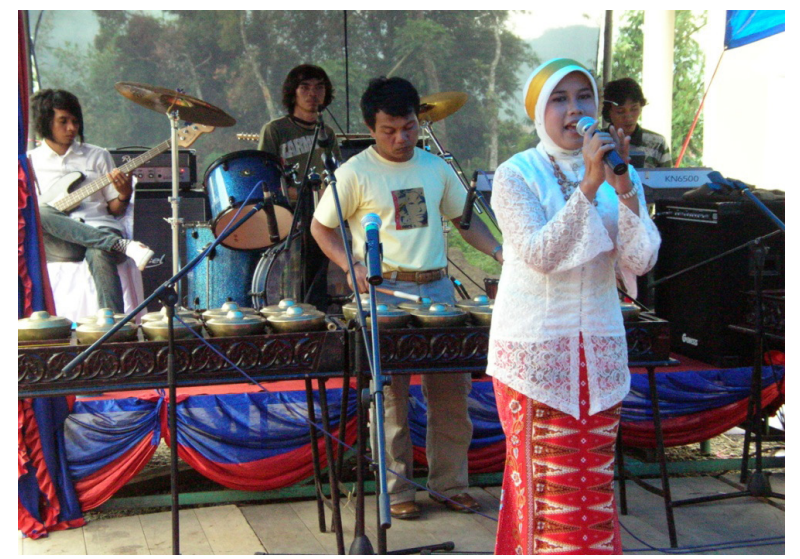

The photo above shows a performance at a wedding celebration in Padangpanjang in 2008. (Photo: Doc. Asril Muchtar)

Talempong kreasi and talempong goyang are fundamentally different to the traditional art of talempong in Minangkabau. Talempong as a traditional folk art is a vessel which represents the process of social and cultural reproduction of the community to which the art belongs, namely the
Minangkabau community. At the present time, the position of talempong has begun to undergo a transformation, in line with the changes taking place in the community, from its previously strong agrarian roots to a more modern, open, industrial oriented community.

The consequence of these changes is that there has been a fundamental change in the predilection of the community, which has ultimately influenced their musical preferences and in turn reflects the social and psychological conditions of the West Sumatran (Miangkabau) community at the present time. Fabio Dasilva states that music is connected to the mentality of its supporting community... The existence of music in a community essentially points to the social phenomenon or social conditions of the community (Dasilva, 1984: 3-4). The emergence of talempong kreasi and talempong goyang is an indication of the social phenomenon and social conditions of the community - the mentality of the community - as an impact of colonialism and the subsequent behaviour which can be referred to as postcolonialism.

The behaviour and mentality of a community after a period of colonialism is related to the conditions and tendencies of the thoughts, feelings, attitudes, and behaviour of a community which is still controlled by the thought concepts of its colonizers. From a cultural perspective, these thoughts, feelings, behaviour, and attitudes are manifested in the appearance of the concept of talempong kreasi and talempong goyang, which symbolize the continuing dominance of colonial ideas - especially with regard to the cultural aspect. This dominance is the reason for justification, as referred to in the understanding of the word transformation.

On the subject of dialectics, Hegel and Marx, as quoted by Khayam, state that transformation can be described as a process of continuous "bargaining". Max Weber believes that a process of transformation takes place through an evolutionary process, in which there is mutual influence between different elements in an "ideal form" that is intentionally created as a model (Khayam, 1990: 324). In general, transformation can be understood as a change that takes place in a community, when the cultural elements [including music] supporting the community experience a dysfunction or 
identity crisis in the community. Van Peursen describes three stages of cultural transformation: mythological, ontological, and functional, and explains that cultural transformation does not necessarily lead to a higher level but rather towards something with a different character. The process of transformation always occurs together with misappropriation or manipulation (Peursen, 1976). The kind of manipulation Van Peursen refers to is evident in the talempong music of the West Sumatra (Minangkabau) community, and can be identified in the aesthetics, form and structure of the group/orchestra, playing technique, and function of performance.

The change - or transformation - in the psychology or mentality of the community, and the manipulation referred to by Dasilva, Khayam, and Peursen, are the consequence of changes in the community, in its shift from a traditional to a more modern way of life. This condition brings about change which leads to anomie in the standard of the values of the community, as explained by Kuntowijoyo below:

The influence of modern culture; commercialization of culture which manifests in changes in scale and increased speed - which may be said to be imbalanced and lead to anomie in the standard of values. Anomie occurs due to the discrepancy between industrialization, technologization, and urbanization on one hand, and conservatism of traditional culture on the other. Industrialization has given rise to a mass culture that leads towards a collective spirit in the value system, technologization has demanded the application of technical methods in all fields, and urbanization has caused a decline in the communal values of a traditional society (Kuntowijoyo, 1987: 11).

Modern culture is identified by rationalization, modern man loses his independence because he is controlled by the culture that he has created himself, and at the same time advances in science and technology have various social and cultural implications. According to Kuntowijoyo, tensions can arise in modern civilization as a result of the endeavour of science to dominate the entire social system. The picture of a mechanistic world becomes the ideal of positivism embraced by the developments in science and technology; the implications of a world filled with technology has its own laws and procedures, a civilization that is technologically-minded and uses only rational calculations and considerations (Kuntowijoyo, 1987: 84-85).

This cultural modernization leads to changes in preference; and these changes in preference in turn alter the social status of a person in the community as a result of his or her education. This kind of change can be observed in the genres of talempong kreasi and talempong goyang in the Minangkabau community. Through education, leading figures and members of the young generation are taught using modern science and knowledge, including knowledge about music based on a modern outlook. The concept of change begins to be planted in their minds, reminding us again of Sztomka's words, that enriching a person's knowledge about change is practically the same as creating change itself. The idea of change is the source for introducing change. The changes that have taken place in talempong originated from the thoughts of a number of leading figures who gained a modern (music) education during the colonial era. After Indonesian independence (the postcolonial era), this concept of change began to enter into the formal education system. Slowly but surely, this resulted in a change in the psychology and mentality of the community.

These psychological changes in the community indicate the phenomenon of change that has occurred in the community - change from a traditional community to a more modern and open community. Numerous new values are apparent, although often still in the shadow of old values. This is also the case with the concept of talempong kreasi and talempong goyang in the life of the West Sumatran or Minangkabau community. The medium of music, which is used as a vehicle for artistic activities in the community, can be used to view the social and cultural phenomena in the community concerned. The emergence of the concept of talempong kreasi and talempong goyang as a portrait of the social life of the Minangkabau community, indicates the existence of new values 
in the midst of the community as a result of the influence of modern culture. Edward Said views these changes from both a Western and Eastern perspective; the West has attempted to textualize the East through its unchanging nature which needs a program of modernization. The culture of the East (specifically its music) is being pulled, in stages, by Western nations, in the direction of new discourse to develop a spirit of freedom, rationality, and industrialization, by offering Western idioms and lifestyles (Said, 2010: 313). The thought patterns of a modern culture, as referred to by Said, are clearly visible in the transformation that has taken place in the life system and culture of the Minangkabau community, especially in the field of the arts, with the appearance of the concept of talempong kreasi and talempong goyang in West Sumatra.

Whether or not people realize it, the change from traditional talempong to talempong kreasi and subsequently talempong goyang is an indication of how power relations, and especially cultural relations - which according to Edward Said work based on the ideology that they embrace - can be referred to as "enjoyable colonization". Although physically the power of the colonists no longer exists, its influence can still be felt, and it may even be said to be continuing and manifesting itself as a form of neocolonialism. Jennifer Anne Fraser writes that this may be due to the mistakes that have been made in the steps taken towards development because it has changed the aesthetics of Minang music - talempong - radically, from its traditional and local roots to become more modern. One institution that is believed to be "at fault" is ASKI (subsequently known as STSI, and now ISI) Padangpanjang, which was the initiator of this change (Fraser, 2007: 124).

The changes in talempong from traditional talempong to talempong pacik, talempong kreasi, and talempong goyang took place through a dialectical process; antithesis is not a final solution but exists within an integration or coalition of two conceptions. Asril says that in terms of its conception, new forms of talempong are understood in a different way by members of the Minangkabau community who still live in their home region and those who have moved to other areas. Minang people living in their home region are easily able to identify talempong renjeang as traditional Minang music or traditional talempong but no longer acknowledge talempong kreasi and talempong goyang as traditional music. Minang people living in other areas, however, especially in Jakarta, are more inclined to refer to all the different types of talempong ensembles (whether traditional, pacik, kreasi, and goyang) as traditional Minang music (Asril, 2012: 18).

Furthermore, in the case of talempong kreasi, when played in the format of talempong renjeang anam salabuhan (an ensemble of six talempong kettles, carried by the players, which academics refer to as talempong pacik), changes have also begun to appear in technical as well as aesthetical aspects. Changes in the technical aspect can be seen in the pairing of the talempong instruments - the talempong dasar (T1 and T3), talempong paningkah (T2 and T4), and talempong anak (T5) - which are used to harmonize or form chord fragments as in Western music. The function of the talempong dasar is to play the melody, the talempong paningkah plays different rhythmic patterns but follows the patterns of the talempong dasar, together forming the framework of the melody, while the talempong anak affirms the melodic form and controls the tempo.

Compare this with the concept of talempong renjeang as described by Andar Indra Sastra in Jurnal Humaniora as follows.

In musical terms, talempong renjeang consists of three pairs of talempong, each pair being known by various different names. This article will use the terms most common to the community to which the music belongs, namely talempong JantanT6 and T1, talempong Paningkah - T5 and $\mathrm{T} 3$, and talempong Pangawinan - T4 and T2. The three pairs of talempong, T6 and $\mathrm{T} 1, \mathrm{~T} 5$ and $\mathrm{T} 3$, and $\mathrm{T} 4$ and $\mathrm{T} 2$, reflect the musical structure of the performance. The talempong pair $\mathrm{T} 6$ and $\mathrm{T} 1$ always begins the performance and acts as the leader throughout. As the leader, the talempong pair T6 and T1 plays the opening melody and guides the imagination of the other players who are playing the talempong pair $\mathrm{T} 5$ and T3 and T4 and T2 so that they can identify the type of guguah (melody) that will be performed. Hajizar states that as the leader, 
the musician playing the talempong pair T6 and $\mathrm{T} 1$ not only has the role of determining the type of guguah to be played, but is also responsible for controlling the danyuik (tempo) of the performance, although the dynamics, or kareh-lunak, are controlled by the talempong Pangawinan (Hajizar, interview, 24-11-2013). This means that musically speaking, each of the talempong pairs has its own primary role, function, and authority - existing within a three-way conception (Sastra, 2017: 62).

Changes in the technical aspect automatically influence the aesthetical aspect (raso). The aesthetical aspect is influenced by the mangkoan bunyi (tuning system) which refers to the diatonic music system. This knowledge of diatonic music is the conceptual foundation used by leading figures who were educated during the colonial era in West Sumatra. Through their knowledge of the diatonic music system, they created a new genre or musical hybrid known as talempong kreasi and subsequently talempong goyang.

\section{CONCLUSION}

The aesthetical nature of talempong kreasi and talempong goyang has philosophically been formed by the aesthetical values of diatonic music - under the umbrella of modern culture. Modern culture has come to exist in a variety of forms, amongst others in the form of new knowledge about music. This new aesthetic has been formed by the system of knowledge about music; it contains an ideological capacity. Ideology works within the domain of a culture (music), thus making the system of Western music appear to be the most natural, as though there were no other choice - leading to the birth of talempong kreasi and talempong goyang.

The emergence of the concept of talempong kreasi and talempong goyang in West Sumatra originated from a group of academics who had gained a modern education during the Dutch colonial era, and their knowledge was implemented along with the establishment of the art academy, Akademi Seni Karawitan Indonesia (ASKI) Padangpanjang, in 1966. Through these leading figures, with their background in Western music education, talempong kreasi was invented and officially became a part of the mandatory curriculum in what was then called the Minangkabau Department. The efforts of these Western educated artists to create innovation and change in the material taught on formal music courses, through talempong kreasi and subsequently talempong goyang, is an indication of the influence of colonialism, which may also be referred to as neocolonialism. Neocolonialism means the continuation of a knowledge system in which the values it embraces continue to be upheld, although physically the area in concern is no longer under the direct influence of the colonizers and no longer a part of the colony. Through graduates of ASKI, which was subsequently known as STSI, and in 2009 became Institut Seni Indonesia (ISI) Padangpanjang, the concept of talempong kreasi and talempong goyang was first introduced in junior high schools (SMP) and senior high schools (SMA) across the whole of West Sumatra.

\section{REFERENCES}

Adam, Boestanuel Arifin (1986/1987). "Talempong Musik Tradisional Minangkabau”. Research Report. ASKI Padangpanjang.

Ali, Matius (2011). Estetika Pengantar Filsafat Seni. Yogyakarta: Sanggar Luxor.

Dasilva, Fabio (1984). The Sociology of Music. Indiana: University of Notre Dame Press.

Faruk (2007). Belenggu Pasca-Kolonial: Hegemoni \& Resistensi Dalam Sastra Indonesia. Yogyakarta. Pustaka Pelajar.

Jennifer Anne, Fraser (2007). "Packaging Ethnicity: State Institutions, Cultural Entrepreneurs, and The Professionalization of Minangkabau Music in Indonesia”. Dissertation. University of Illinois at Urban-Champaign.

Hanefi, et al. (2004). Talempong Minangkabau Bahan Ajar Musik dan Tari. Bandung: P4ST UPI.

Hastanto, Sri, (2012). Ngeng \& Reng: Persandingan Sistem Pelarasan Gamelan Ageng Jawa Dan Gong Kebyar Bali. Surakarta: ISI Press.

Hauser, Arnold, (1974). The Sociology of Art. Chicago: The University of Chicago Press.

Kayam, Umar (1990). Transformasi Budaya Kita dalam Menerawang Masa depan Ilmu Pengetahuan, Teknologi dan Seni Indonesia. Pub. ITB. 
Kuntowijoyo (1987). Budaya dan Masyarakat. Yogyakarta: P.T. Tiara Wacana.

Laksono, Joko Tri (2008), ”Menelusuri Karya dan Karsa Manthou's Sebagai Seniman dan Pecipta Campursari in Resital Jurnal Ilmiah Seni Pertunjukan, Volume 9 No. 2 - December 2008, 87-101.

Muchtar, Asril. "Dilematika Perkembangan Ansambel Talempong Minangkabau". Paper presented at World Music Seminar in Ethnomusicology Department. Institut Seni Indonesia (ISI) Yogyakarta, 31 March 2012, page 5, (2012).

Said, Edwar (2010). Orientaslime: Menggugat Hegemoni Barat dan Mendudukan Timur Sebagai Subjek. Translation by Achmad Fawaid. Yogyakarta: Pustaka Pelajar.

Santoso, Budi (2003). Identitas dan Poskolonialitas di Indonesia. Yogyakarta: Pub. Kanisius.

Suryajaya, Martin (2016): Sejarah Estetika. Jakarta Barat: Gang Kabel.

Sastra, Andar Indra (2017). The Aesthetics of a Three-Way Pattern: The Musical Concept of Talempong Renjeang and the Social System of The People of Luhak Nan Tigo Minangkabau. Humaniora, 62, pp. 61-71.
Sztompka, Piotr (2008). Sosiologi Perubahan Sosial, Translation by Alimandan. Jakarta: Prenada Media Group.

Peursen, Van (1976). Strategi Kebudayaan. Yogyakrta: Penerbit Kanisius.

Pramono, Kartini (2009). Horizon Estetika. Yogyakarta: Kahfi Offset Fakultas Filsafat Universitas Gadjah Mada.

\section{Informants:}

Asril Mucthar (age 54), PhD in Art Studies; Lecturer on Karawitan Study Program Institut Seni Indonesia (ISI) Padangpanjang.

Alfalah, (age 45), Master of Arts; Lecturer on Karawitan Study Program Institut Seni Indonesia (ISI) Padangpanjang.

Hajizar, (age 56), Master of Arts, Art Observer; Lecturer on Karawitan Study Program Institut Seni Indonesia (ISI) Padangpanjang.

Murat St. Saidi, retired teacher from Sekolah Menengah Kejuruan (SMK) 7 Padang. 